Article

\title{
Trump Veganism: A Political Survey of American Vegans in the Era of Identity Politics
}

\author{
Corey Lee Wrenn \\ Political Science \& Sociology, Monmouth University, West Long Branch, NJ 07764-1898, USA; \\ cwrenn@monmouth.edu
}

Received: 29 August 2017; Accepted: 12 November 2017; Published: 17 November 2017

\begin{abstract}
Often stereotyped as being apathetic to the human suffering, the American vegan movement has historically failed to build alliances with other social justice movements. As intersectional feminism gains a foothold in the movement and external political crises challenge the movement's frame of reference, the role that identity plays in movement progress has become a serious concern. Using the 2016 election as a flashpoint, this article considers if the identity backlash characterized by the Trump campaign finds parallels in the American vegan movement. A survey of 287 American vegans finds limited evidence of Trump veganism, defined here as a single-issue focus on speciesism that rejects the relevance of human-experienced systems of oppression. However, respondents do find that movement diversity efforts are insufficient, especially when controlling for race and gender. Most respondents were ethically-motivated vegans, liberal voters, and intersectionally-oriented activists who reported multiple engagements with various leftist movements. Only four percent of respondents voted Trump, while $14 \%$ agreed with or were neutral about Trump's campaign promise to put "America first". Those who were vegan for reasons of self-interest and had been vegan for less than a year were significantly more likely to support Trump's conservative agenda and were slightly less likely to participate in other social movements.
\end{abstract}

Keywords: Animal rights; identity politics; political attitudes; social movements; veganism

\section{Introduction}

Comprising about $2 \%$ of the American population [1,2], vegans (those who eschew Nonhuman Animal products) tend to be middle-class, white, female-identified, educated, agnostic or atheist, and urban-dwelling [3]. Numerous studies have indicated that vegans are predominantly liberal or left-leaning [3-5]. A Pew Research Center survey found that $15 \%$ of liberal democrats are vegan or vegetarian, as compared to only 4\% of Republicans [6]. Attitudinal research from the 1990s found that $35 \%$ of Nonhuman Animal rights activists identified as Democrats, while 37\% identified as (mostly left-leaning) Independents, and 14\% identified as Republicans [7].

However, political affiliation alone does not accurately portray the vegan demographic. McGarry and Jasper [8] emphasize that social movements must grapple with an "identity dilemma" as they struggle to find a balance between the important mobilizing capabilities of identity politics and the dangers of exclusion and exaggerated homogeneity. As is the case with other leftist movements $[9,10]$, an ethic of liberalism that is apprehensive about identity politics and lacks a critical anti-capitalist analysis prevails in the professionalized American vegan movement. Although vegetarianism and veganism have been closely associated with abolition, feminism, and other social justice movements for at least two centuries [11], there lurks beneath the surface a streak of conservativism. Specifically, vegan researchers have indicated that the American vegan movement frequently exhibits multicultural insensitivity $[12,13]$. External forces can shape a movement as much or more than internal ones, however, compelling an examination of the cultural influence that identity politics wield in wider 
American society. Notably, the election of conservative billionaire Donald Trump has created concerns that identity politics are divisive and multiculturalism is threatening. As citizenship and belonging have been shaped by whiteness [14], the white-dominated American vegan movement may be adopting its praxis from these environmental trends by rejecting diversity and favoring isolationism.

For those engaging the difficult work of intersectional consciousness-raising in vegan and nonvegan spaces, Trump's campaign tactics and their reception are familiar. Breeze Harper [15], activist-scholar founder of Sistah Vegan, notes that Trump's rise was plainly predictable given the systematic resistance to critical race work she has observed in the vegan movement. Intersectionallyminded activists who disrupt privilege mechanisms with identity politics are subject to Trumpian "law and order" efforts to diminish the relevance and visibility of "the other". At least one vegan organization, Collectively Free, experienced a serious threat to its organizational identity and conflict management policy when one of its organizers avowed his support for Trump [16]. Although existing research supports the leftist tendencies of American veganism, current criticisms indicate that it may not be prudent to presume the vegan identity radically liberal, as many activists embrace alternate political leanings.

While intersectional feminists have published extensively on conservatism in the movement, little empirical research has been conducted to map vegan understandings of race, class, and gender identity. Demographic research on the vegan community is limited, dated, and is often subsumed within larger studies of dietary restrictions and vegetarianism (when compared to veganism, vegetarianism is more likely to be apolitical and its boundaries are more fluid). The research presented herein spotlights vegan political attitudes in the dawn of a new era of American conservativism. The vegan movement has a history of exploiting sexism, racism, and colonialism to promote its agenda and achieve resonance. The concern is that this dark legacy may be emboldened and rejuvenated by a 21st century of hyper-nationalistic, pro-capitalist populism (hereafter referred to as Trumpism). This study explores the vegan movement's contentious relationship with identity in light of the Trumpian political climate and in the context of the movement's institutional history. While ideologies that are tied to Trumpism are certainly not new, the election brought the politicized nature of identity into the cultural consciousness, creating a useful window of opportunity for research.

\section{Literature Review}

\subsection{Nonhuman Animal Advocacy as a Project of White Supremacist Nationalism}

Despite its historical association with social justice movements, the Nonhuman Animal rights movement (the progenitor of veganism), is rooted in colonialist and racist resistance to egalitarianism. Following the abolition of slavery, concern for the welfare of Nonhuman Animals became a means of demonstrating white supremacy $[17,18]$. This was evidenced in early charity appeals as well as the American government's targeting of the lower classes and people of color in anti-cruelty laws. Nonhuman Animal welfare was a symbol of Black, Brown, and Celtic savagery, and it created a rationale for social control $[19,20]$. From the early 1800 s onward, humaneness would come to symbolize civility and the naturalness of class divisions. It would be an important component in the project of nationhood and empire. Indeed, the goal of Nonhuman Animal "rights" itself banks on the language and symbolism of nationalism in its bid to grant Nonhuman Animals protection of their individual interests. It is an approach that has been criticized as both unrealistic and unnecessarily antagonistic [21,22].

The Nonhuman Animal rights movement and its vegan community would never fully come to grips with its oppressive legacy. As the movement entered its second wave in the mid-20th century, racism, sexism, and disdain for immigrants and non-Westerners continued to serve as fodder for campaigning [23]. Campaigns drew on the preexisting prejudices of the American populace with hopes of appealing to privilege and in-group solidarity. The strategic exploitation of stigma is exemplified in the vilification of "vain" women who wear "fur", "barbarous" Asians who consume dogs and cats, 
and "savage" Blacks engaged in dog "fighting". As was the case in the 19th and 20th centuries, compassion for other animals in the 21st century became a conduit for American identity and perceived superiority.

\subsection{Vegan Feminism and Nonhumans First}

Identity politics would reach a boiling point in the mid-2010s as intersectional feminist theory began to infiltrate movement discourse. Ecofeminism had been contributing these ideas to the anti-speciesist dialogue since the 1970s [24], and abolitionists of the late 20th [25] and 21st centuries drew extensively on human rights frames, but it would find its second wind as a new generation of feminists began to apply these theories in third wave mobilization efforts. Organizations such as The Advocacy of Veganism Society (TAVS), Food Empowerment Project (FEP), Project Intersect, Sistah Vegan, Vegan Advocacy Initiative, Vegan Feminist Network, Vegan Princess Warriors Attack, Vine Sanctuary, and other female-led grassroots collectives embraced intersectionality theories as fundamental to their mission. This new dialogue reflected the increasing platform that was granted to vegan feminists who had been critical of sexist and racist campaigning and movement dynamics, but it also reflected the increasing professionalization of the movement. As grassroots collectives moved towards nonprofitization, they grew more conservative in claimsmaking and tactics. Intersectionality rhetoric offered a more palatable replacement to the more contentious and disruptive language of anti-speciesism. The singular focus on speciesism that once characterized leading organizations would give way to anthropocentric multiculturalism and its potential compatibility with plant-based eating.

Direct action vegans were some of the first to react to this changing focus, insisting that the movement commit to putting "nonhumans first". The 2014 "Nonhumans First Declaration" promoted by the transnational collective 269life, for example, insisted that no activist be excluded due to their adversarial position on human justice (a number of direct action movement leaders had been criticized for their misogynistic and racist posturing), no tactic be excluded due to its conflict with human justice, and that humans must "free their own slaves" (a reference to speciesism) before seeking their own justice. In other words, the Nonhuman Animal rights movement should center Nonhuman Animals at all times, no matter the cost to others. For 269life, this abrasive position is justified by the immediacy of nonhuman suffering: "The non-human animals are in a situation of immediate emergency and need all the help they can get!"

The "nonhumans first" campaign was fundamentally a backlash against feminist threats to white male privilege. The feminized Nonhuman Animal rights movement is dominated by white men who experience a glass escalator effect in quickly rising to become celebrity leaders and grassroots heroes. The feminist critique disturbs the vital flow of adoration that supports and motivates these activists, particularly in the direct action faction. The attack on identity politics was also a resistance to perceived deradicalization. Although vegan feminist claimsmaking emerged from radical grassroots efforts, it was coopted for bureaucratic interests in an era in which multiculturalism sells. Instead of attributing this appropriation to the pull of nonprofitization, radical activists would dismiss feminist theory itself.

\subsection{Trump Veganism}

The resistance to feminist goals in the vegan movement is therefore a longstanding source of tension. As identity trouble has simmered for decades, the present discomfort with efforts to diversify cannot be said to be a direct result of the more recent election of Donald Trump. Yet, Trumpian politics are relevant in that they reflect the general sentiment of a historically white-led patriarchal society that is begrudgingly coming to terms with a diversifying population that is emboldened with higher expectations of equal opportunity. This matters to movements because activists do not exist only in social movement spaces; they also inhabit Trump's America. Research into 2016 voting patterns finds that poverty and unemployment do not necessarily correlate with support nationalism and populism. Instead, it is related to racial isolation, restricted social mobility, and lower social capital [26]. As the 
vegan movement is white-dominated and predominantly middle-class, there is at least some reason to believe that Trumpism is resonating.

Trump's rise was partly made possible by his innovative construction of identity. In a world of increasing multiculturalism and disintegrating privileges for dominant groups, he was able to devise a new shared identity that is characterized by its resistance to assaults on traditional social structures [27]. There is some evidence that resistance to diversity is formulating a new shared identity among traditionalist vegans as well. As inclusivity ideologies began to threaten the status quo of power and privilege in vegan spaces, they have been disparagingly reframed by some as "political correctness". For anti-intersectionalist vegans, trigger warnings and hurt feelings are believed to disrupt an activist's ability to do what is necessary to advocate for nonhuman interests. Just as Trump supporters reproach accusations of ethnocentrism and racism in their desire to increase national security and block immigration, for example, traditional vegans reproach these same accusations that emerge from plans to target minorities in campaigns and block minorities from movement participation. Some activists, such as noted theorist and monied Rutgers University professor Gary Francione, would go so far as to accuse vegan feminists of bigotry [28] and "unabashed narcissism" for their criticisms of white male supremacy in the movement [29]. Identity politics, he warns, a-re the "moral rot of the animal movement".

Resistance of this kind indicates a desire to defend movement boundaries from "others", but not all resistance to diversity stems from a fear of threatened privilege. Like Trump voters, many vegans, too, are frustrated by years of stunted progress for "the forgotten". Activist impatience and dissatisfaction with the unrelenting suffering of other animals has long been the bane of American veganism. From this frustration, the second wave of Nonhuman Animal rights activism in the late 20th century embraced direct actions, such as street protest, illegal open rescues, vandalism, and extreme intimidation of employees in speciesist industries. At the time, this represented an important invigoration, as the post-war movement has been in a state of relative inactivity and bureaucratic stagnation [30,31]. However, direct action since then has declined in popularity, and today's professionalized movement has withdrawn its support for this approach, as violent and illegal activism complicates resource mobilization [32]. Trumpian politics promise to cut through red tape and forge a shortcut to a better world [27]. It is all too tempting to abandon cordiality in a no holds barred scramble for nonhuman rights. Indeed, the discussion of theories and effectiveness are even stigmatized as counter to Nonhuman Animals who are "suffering right now" and "can't wait". "Armchair activists" and "keyboard commandos" are portrayed as self-absorbed or even cowardly. This celebration of "doing something" and the dismissal of cooperative discussion are gendered and reflect the male dominance of the movement, but this is also a key component of Trump's campaign, based as it was on immediate action, consequences be damned.

\subsection{Intersectionality and Movement Success}

Fierce debate over tactics and frustration over the slowness of social change is nothing new for social movements, nor is the question of whether or not to pursue cross-movement alliance-building. Resistance to intersectional frameworks is an unfortunate legacy of veganism and anti-speciesism, but the desire to incorporate these frameworks can be chronicled as well. First wave anti-speciesist mobilization was heavily entangled with anti-slavery efforts, women's rights, children's rights, and even India's and Ireland's Home Rule movements [11,17,20]. Many activists were divided in their attention, lending their services to multiple causes at once. Intersectionality was common in theory and practice. Britain's Humanitarian League, which operated in the late 19th and early 20th centuries, was explicitly multi-issue in is focus on prison reform, labor rights, and secularism in addition to Nonhuman Animal rights. In America, there were projects such as Fruitlands, a utopian anti-slavery community in which Nonhuman Animals were not to be exploited and egalitarian ideals could be enacted [33]. The Women's Christian Temperance Union (WCTU), American Humane Association (AHA), and Society for the Prevention of Cruelty to Animals (SPCA) were also deeply involved in 
child welfare, prison aid, poverty relief, and more [17]. This is not to characterize early intersections as without fault. For instance, the Humanitarian League frequently drew connections between the various injustices and hosted collaborative meetings with other movements [34], but it waivered in its support for suffragettes and avoided female professional or celebrity endorsement for its campaigns [35]. In America, intersectional welfare organizations were hostile to labor organization and also aggravated communities of color by portraying gentile white women as the epitome of social justice praxis. Meanwhile, the WCTU became so distracted by its commitment to universal kindness that it gradually abandoned Nonhuman Animal interests.

\subsection{Social Movement Structural Constraints}

A collective's awareness and reaction to identity is shaped by structural conditions. The single-issue focus that inhibits coalition-building for most movement entities is tied to the rise of neoliberalism in the late 20th century. The subsequent incorporation of social justice collectives into the state- and industry-supported nonprofit sphere has created intense competition and a need to specialize [36]. Legal restrictions on American nonprofit activities further discourage coalitions regarding electoral activities and labor unions [37]. The result is a siloing effect, and movement ambivalence to the struggles of its competitors is a predictable consequence. For the vegan movement, this disincentive to engage other movements is amplified when disenfranchised demographics are stereotyped as antagonistic to other animals, or, when the interests of Nonhuman Animals are thought to be sidelined by the "distractions" of racism, sexism, and so on.

As organizations professionalize, they also moderate and deradicalize their tactics and ideology [32]. Although it is a rational maneuver needed to access a larger pool of resources, this tactic comes at a cost. Consider the feminist movement. Dealt a serious blow following Trump's election, it was forced to take a hard look at the role identity politics played in repertoires and resonance. A writer for the New York Times wisely observed that Trump's win on a platform of blatant misogyny, "[ ... ] burst the bubble of cheery pop feminism, which had achieved its huge popularity at the expense of class consciousness and racial solidarity" [38]. By appealing to the largest possible audience with a depreciated message, a movement risks trading in cultural currency for meaningful social change. For the American veganism, "cheery pop veganism" that lacks a critical engagement with intersections of race, class, and gender could find similar barriers to social justice.

Difficult though it may be, the effort invested in the construction of an intersectional vision is worthwhile, as alliance-building is critical for the success of social movements. Well-allied movements experience and increase in protest, and the probability that they will create coalitions in the future is heightened [39]. In a study of successful coalition building between movements engaging with environmentalism and peace, Beamish and Luebbers [40] note that movements were able to overcome their positional variances regarding race, class, and so on by affirming one another's interests, practicing reflexivity, and sharing tasks. Researchers indicate that the American vegan movement is lacking in these abilities $[12,13]$. This deficiency could spur from the historical race and class privilege that is enjoyed by most vegan activists, which discourages their ability to identify positional variances and how to overcome them in a fair manner. While this study does not test this historical association, it does contribute findings from a survey of current vegan political attitudes and their perceptions of other social justice matters. As such, it can be ascertained as to whether or not fertile ground exists for future alliance making, and where Trump-era veganism can be placed in the historical trajectory of the movement.

\section{Methodology}

\subsection{Sample}

Are American vegans of the "Nonhumans First" persuasion, or are they committed to intersectional connection? Internet surveys were disseminated to ascertain the political attitudes 
of current vegans given recent conservative trends in American politics and identity tensions erupting within the American vegan movement. Veganism has many meanings and associations. It can refer to one's diet, political philosophy, or a combination of the two. For instance, some identify as vegan because they have eliminated animal products from their diet for health or aesthetic reasons, while others identify as vegan because they are concerned about the disenfranchisement of Nonhuman Animals and avoid animal products of all kinds, including animal-based clothing and entertainment. Some may or may not concern themselves with Nonhuman Animals, but they nonetheless understand their abstention from animal-based foods to be political in that it resists systemic racism, colonialism, or sexism. To account for this variation, vegans were asked to self-identify. Participants must have been vegan for at least six months, be of adult age, and have resided in the United States for at least one year (citizenship was not questioned).

\subsection{Design}

The survey asked participants to report their length of time as a vegan, their primary motivation for remaining vegan, and the strongest influence in motivating them to go vegan (Supplementary Materials File S2). Basic demographic information was requested, such as gender, race, age, and state of residence. Participants were asked to report their political affiliation, their 2016 presidential voting behavior, their level of activism and political engagement, and their affective response to Donald Trump's election. Respondents were also asked to rate their involvement with other social movements that share the arena with the vegan movement, such as the Black Lives Matter movement and feminism. They were asked to rate how relevant these competing movements are to the vegan project and they were provided a series of questions intended to measure comfort level with diversity in the vegan movement. Likewise, participants were asked to rate their level of contact with minority groups and people who differed from themselves, and how comfortable they would be with these people sharing the movement space.

This electronic survey that took between 5 and $10 \mathrm{~min}$ to complete was created using Qualtrics. Responses were collected between 4 March and 30 April 2017. The survey was advertised through various vegan Facebook groups and Facebook pages, starting with my own personal author account and Vegan Feminist Network. It was also shared through H-Animal (an academic listserv hosted by H-Net) and the American Sociological Association's Animals \& Society section listserv. Recipients were asked to share among their networks. This study is restricted to vegans with internet access, but, because vegans are a rather small and dispersed group in the population, convenience sampling of this kind was necessitated. Another limitation is that, in my attention to attitudes about minorities, I failed to ask respondents to report their experiences with whites, heterosexuals, able-bodied persons, or other dominant groups. In doing so, I effectively normalized the dominance of privileged groups in vegan spaces. Some respondents also expressed their dissatisfaction that their favorite social movements were not listed in the survey, although an "other" option was provided with an opportunity to fill-in-the-blank.

\section{Results}

\subsection{Demographics}

Three hundred and sixty-four persons responded to the survey, 287 of whom identified as a vegan who had resided in America for at least one year and were thus qualified to participate. Half of respondents $(49 \%)$ were long term vegans of five years or more, while $42 \%$ were vegan between one-five years and $8 \%$ were new vegans of less than one year. Eighty-two percent indicated that Nonhuman Animal rights/welfare was the primary motivator for their veganism, while $11 \%$ indicated environmental concerns and $7 \%$ indicated personal health. There were a number of influences that inspired the respondents to become vegan. Approximately one in four indicated that they figured it out on their own, while about a fifth indicated the influence of a friend or family member. 
Vegan documentaries and the efforts of Nonhuman Animal rights organizations or social media celebrities were also relatively influential.

Only $55 \%$ of the respondents chose to disclose their gender, and $75 \%$ of these identified as female, while $21 \%$ identified as male and $1 \%$ identified as nonbinary. Sixty-five percent identified as heterosexual, $13 \%$ identified as bisexual, $7 \%$ identified as homosexual, and $15 \%$ identified as queer or another non-heterosexual identity. Seventy-nine percent identified as white, while $6 \%$ identified as Asian, $5 \%$ identified as mixed, $5 \%$ identified as Latinx, 2.5\% identified as Black, and $1 \%$ identified as Native American. Nine out of ten respondents identified as able-bodied. The largest religious identity was atheist and agnostic (73\%), followed by Christian ( $8 \%$ ), and Jewish (7\%). The remaining $12 \%$ indicated "other", most of which were variations of spiritualism. Respondents were skewed younger, with $22 \%$ between the ages of 18 and $25,35 \%$ between 24 and $34,21 \%$ between 35 and 44 , and $14 \%$ between 45 and 54 . Respondents were geographically dispersed, although half of the respondents resided in California, New Jersey, and New York. About half were also urban-dwelling, while $40 \%$ were suburban, and $8 \%$ were rural. Income was well distributed with $29 \%$ living in a household with an income of less than $\$ 35,000,18 \%$ between $\$ 35,000$ and $\$ 55,000,13 \%$ between $\$ 56,000$ and $\$ 75,000,14 \%$ between $\$ 76,000$ and $\$ 100,000$, and $25 \%$ over $\$ 100,000$.

\subsection{Political Identity}

Almost half (46\%) of respondents identified as Democrat, while $9.4 \%$ identified as Green, and just $3.1 \%$ identified as Republican. Independents (6\%), socialists (3.5\%), anarchists (3.5\%), and progressives (3.1\%) were also represented, however $19 \%$ of respondents reported having no party identification at all. Sixty-five percent voted Clinton in the 2016 election, $4 \%$ voted Trump, 16\% voted Stein, and 9\% did not vote at all due to abstention or eligibility restrictions. Eighty-five percent reported that they considered themselves to be politically engaged, while $70 \%$ indicated that they considered themselves an activist. Ninety-one percent reported feeling worried that social problems will increase with the election of Trump, while $4 \%$ were hopeful that problems would decrease with the election of Trump and $3.2 \%$ were unsure. Over $6 \%$ of respondents agreed with Trump's campaign promise to put "America first", $8 \%$ were neutral, and $86 \%$ disagreed.

Length of time as a vegan was correlated with support of Trump; $32 \%$ of those who had been vegan for less than a year indicated that they either agreed with or were neutral about Trump's campaign promise, when compared to just $11 \%$ of those who were vegan for more than five years (Supplementary Materials Table S1). The Pearson Chi-Square was 6.5 with a $p$ value of 0.4 , demonstrating a modest strength in the relationship between length of time as a vegan and support for Trump. Sixteen percent of those who went vegan for reasons of personal health thought that social problems would decrease with Trump's election or were neutral, as compared to just 9\% of ethics-motivated vegans and $7 \%$ of environmentally motivated vegans (Supplementary Materials Table S2). Likewise, $21 \%$ of health-motivated vegans agreed with or were neutral about Trump's campaign promise to put "America first", as compared to $15 \%$ of ethics-motivated and $7 \%$ of environmentally motivated vegans (Supplementary Materials Table S3). Recall, however, that ethical vegans composed the majority of respondents, meaning that the pools of health and environmental vegans were much smaller and less generalizable. This is also the case with rural respondents. Few $(8 \%)$ identified as rural inhabitants, but $14 \%$ of them were neutral or hopeful about Trump's election, when compared to just 9\% of urban dwellers. Subsequently, the Pearson Chi-Square scores for these relationships were weak. Gender mattered, however. The Pearson Chi-Square for gender by feelings about the election was 2.8 with $p$ value of 0.4 , demonstrating a modest relationship between gender and support for Trump (Supplementary Materials Table S4). The same result surfaced when comparing sexuality by feelings about the election. 


\subsection{Intersectional Awareness and Diversity}

About three in four respondents identified as an activist, and this was not a significant predictor of attitudes about the election. Only 7\% reported that they did not participate in social movements other than veganism. Twenty-two percent reported involvement in disability rights, $25 \%$ in homelessness advocacy, $27 \%$ in fat acceptance/body positivity, 29\% in prison abolition, 31\% in labor rights, 33\% in indigenous rights, $42 \%$ in Black Lives Matter, 57\% in LGBTQ+ rights, 67\% in feminism, and 79\% in environmentalism. In addition, respondents indicated involvement with several other racial advocacy efforts, as well as education and food security. When controlled for political attitudes, those who were hopeful, unsure, or unopinionated about Trump's win were less involved, with an average involvement with 3.1 other movements. Those who were worried about Trump's election averaged involvement with 4.5 other movements. However, an independent t-test presented a $\mathrm{t}$ score of 2.2 and a $p$ value of 0.114 , suggesting that the relationship between feelings about Trump's election and social movement involvement was not a significant one (Supplementary Materials Table S5). Involvement was only slightly higher for respondents who indicated that they supported Trump's "America First" campaign or were unsure or unopinionated. These individuals were involved with an average of 3.6 other movements. Those who disagreed with Trump's campaign, however, were involved with 4.5 other movements. Again, an independent t-test did not find significance.

Respondents reported an average amount of contact with minorities, although they reported slightly more contact with LGBTQ+ and lower income people, and slightly less contact with disabled persons. Most reported much higher levels of comfort when asked about how they would feel about sharing space at a vegan social or political event with a person or persons from an oppressed group. When asked if they feel awkward in vegan spaces when in proximity with people from different backgrounds, the response averaged just 2 (on a scale of 1 to 10), indicating little awkwardness. Regarding their comfort level with sharing a vegan space with someone with a political position different than their own, respondents indicated considerable discomfort with an average of 7 . When controlled for political party affiliation, Democrats averaged slightly lower in comfort level that other affiliations (including those who claimed no affiliation) at 6.5.

Respondents indicated a score of about 5 on a scale of 1 to 10 in their opinion that Black Lives Matter, prison abolition, indigenous rights, LGBTQ+ rights, body positivity, disability rights, housing rights, and labor rights were relevant to veganism. Religious advocacy was indicated as less relevant, while feminism was considered more relevant. Environmentalism scored highest with an average 9.5 out of 10 in perceived relevancy to veganism. Respondents indicated low levels of belief that the vegan movement adequately addresses issues of ageism, ableism, racism, religious discrimination, discrimination based on political affiliation, and classism, but believed there to be average attention given to sexism and heterosexism.

Composite variables were created for questions relating to attitudes and actions that are related to diversity, and reliability was strong. The Cronbach's alpha statistic testing reliability for the measure of contact with minorities was 0.737 . For comfort with minorities, it was 0.919 . For belief that the vegan movement effectively handles diversity issues, it was 0.931. Finally, the Cronbach's alpha statistic for questions relating to how relevant other movements are to veganism was 0.943 . Respondents averaged a response of just 4 out of 10 in belief that the vegan movement is dedicated to fostering diversity, dropping to 3.7 out of 10 when controlled for race as racial minorities were less confident. When asked if the vegan movement has a climate that feels welcoming to them, respondents averaged 6.1, but this dropped to 6 when controlled for gender and 5.7 when controlled for race. When asked if they felt comfortable discussing diversity in the movement, the average was also 6.1, indicating relative comfort. This indicator was not significantly impacted by race or gender. Perceived political intelligence was high. Respondents averaged a score of 8 when asked if they felt informed about inequalities impacting humans, and 8 was also the average indication for the belief that veganism should be involved with these inequalities (race and gender did not significantly impact this response). When asked if the vegan movement should put nonhumans first, the average score was 4.6, and was not significantly impacted 
by race or gender. This suggests that vegan activists are interested in an intersectional approach that addresses human inequalities, but perhaps not at the expense of Nonhuman Animals. In the question that recorded participant involvement in other social movements, many respondents utilized the "other" box to list "animal rights" even though the survey clearly presumed their veganism and the question specifically asked them to identify other movements. This may indicate a resistance to discussing social justice efforts in vegan spaces without centering Nonhuman Animals. While a cross tab analysis (Supplementary Materials Table S6) found that 35\% of those who agreed with Trump's America First campaign also agreed with putting nonhumans first, $43 \%$ of those who agreed with Trump's America First campaign did not agree with putting nonhumans first, indicating the relationship between the two was not significant.

\section{Discussion}

This study constructs an identify profile of the American vegan movement, which finds them to be an extremely liberal political group, with most turning to veganism for ethical reasons, identifying as atheist, voting left, and supporting diversity. These results support previous research that finds vegans to be left-leaning [7] and concerned about equality and social justice [5]. They also support observations that political ideology and environmental concern are correlated [41]. Identity politics have the potential to compress complex intersections of race, class, gender, and other distinctions, creating an artificial either/or framework [42], but limited evidence in support of this potentiality surfaced in the survey. Vegan intersectionalists are correct in their observation that patriarchal, antagonistic claimsmaking dominates Nonhuman Animal rights rhetoric [12,13,18,24], but they are incorrect to presume that the loudest opinions are necessarily the most common ones. Fears that the identity politics that facilitated Trump's exclusionary agenda may be represented in this movement as well were weakly supported. To the contrary, the results demonstrate that vegan activists are highly involved activists, with most indicating participation in multiple other social movements. This counters the stereotype that vegans only care about Nonhuman Animals and neglect human issues. Anti-intersectional perspectives in the American vegan movement are truly marginal, as American vegans define themselves as allies to many causes. Francione's [29] accusation that intersectionality's identity emphasis represents narcissism is ill-fitting given the high levels of volunteerism evidenced among participants. In an attitude survey of Nonhuman Animal rights activists conducted twenty-five years ago, researchers found considerable affinity with environmentalists and feminists [7], and this study supports that the affinity remains strong today. In fact, this study supports an intersectional awareness that mirrors anti-speciesism activism of the 19 th century.

Rothwell and Diego-Rosell [26] find support for Trumpian politics rooted not in poverty or working-class status, per se, but more specifically in racial isolation, low social capital, and low opportunities for social mobility. American vegans may experience racial isolation, but most do come from relatively privileged backgrounds, and, most importantly, they are usually well educated. Gusterson [43] identifies education as a key source of political disparity, with those lacking higher education more likely to be alienated in an increasingly service-oriented economy. Education is also linked with greater support for liberal values. It is likely that, for vegans, education is creating a buffer to Trumpian conservatism. Another reflection of this educational correlation is found in the high rate of atheism, a trait that is little examined in previous attitudinal research. Indeed, previous research has highlighted the movement's distrust of science given its association with vivisection [7,35], but science strongly shapes the epistemologies of atheists. That said, social desirability bias was likely an influence on data regarding personal feelings toward the importance of other social movements and diversity. This survey could have been improved by incorporating open-ended questions that depict scenarios that activists might experience in real life. Examples might include, "An American animal rights organization has created a campaign against dogfighting in Black communities, is this a campaign you would support? Why or why not?" Open ended, example-oriented questions such as these would 
allow for more nuance, as these are topics that are hotly debated in the informal collaborative spaces of vegan social media.

There is reason to suggest that an improved question design would be fruitful. Although just 11 of the 287 respondents voted for Trump, attitudinal questions about Trump's campaign promises and potential impact on the future showed more conservativism amidst the sample. The rhetoric of Donald Trump has potency for a small, but significant portion of respondents, particularly those who were short term vegans of less than one year and those who went vegan for reasons of personal health. This correlation between veganism and political leanings may indicate that vegans experience political learning as they transition. Alternatively, psychological research has confirmed that conservative vegans and vegetarians who adopt a plant-based diet for purposes of personal health rather than social justice are simply more likely to recidivate [44]. Sociality also matters. If the vegan identity is tightly constructed as far left, vital vegan networks may not be open to those aligned elsewhere on the political spectrum. Liberal vegans in this study, who constituted the majority of respondents, were less comfortable in interacting with persons from different political affiliations. Non-liberal new vegans may find the community unwelcoming, and, if so, would find veganism difficult to maintain given the importance of networks for attracting and sustaining vegans $[45,46]$.

\section{Conclusions}

The advancement of human justice need not come at the expense of other animals, and any suggestion to the contrary risks cultivating a false dilemma. In fact, holistic logics of equality are beneficial for all marginalized groups. This study depicts an American vegan movement that understands that the struggles for human and nonhuman liberation are not in conflict. In dismantling this false dilemma, however, activists and policy makers must also be cognizant of the potential for false equivalency. Oppression is intersectional, but all oppressions are not identical in design or impact. Suggesting that human inequality is on par with nonhuman inequality could diminish the tremendous suffering that is unique to the nonhuman experience. Likewise, pulling on human frameworks to construct a grand narrative of suffering is likely to alienate disenfranchised human groups, especially as they have historically been likened to Nonhuman Animals in an attempt to naturalize their disenfranchisement. "Species-blind" ideologies that reduce difference ("we're all animals") can distort and distract. The goal of diversity in claimsmaking and institution-building is not to erase difference in a "melting pot", but rather to respectfully acknowledge differences in access, interests, and needs. Respondents in the survey seem to understand this in their reluctance to disagree with the notion of putting "Nonhumans first", as well as the ambivalence toward Trump's campaign held by a small, but notable, percentage.

That said, a number of limitations must be revisited. First, the sample appears to be skewed feminist based on the convenience sampling that targeted Vegan Feminist Network and other intersectional internet spaces. That almost half of the respondents chose not to report their gender and $35 \%$ identified as non-heterosexual suggests a sample that has a higher than average consciousness to identity politics and oppression. Second, this study focused primarily on comfort and familiarity levels with minorities, and did not measure comfort and familiarity levels with dominant groups. Furthermore, the social desirability bias is likely at work, discouraging respondents from reporting true attitudes about socially undesirable values, such as racism and sexism. Online surveys are also limited in their ability to measure the depth and nuance of political attitudes. Additional qualitative interviewing could prove a fruitful avenue for examining this research topic.

Social movement isolationism is a tactic that is just as unsustainable and unrealistic as Donald Trump's "America first" nationalistic campaign, but there is only limited support for its existence in this study. Social movement researchers extoll the importance of coalition-building, but they also acknowledge that it is much easier to achieve for movements with shared histories and networks [47] that are facilitated by ideological convergence [48]. Given the vegan movement's history of antagonism to human justice causes, this coalition-building will be a difficult but necessary goal to achieve. 
As previously discussed, there is evidence that this is a process that is well underway, and the recent growth of vegan intersectionality, if nurtured, could open the door for increased cooperation. Respondents in this survey, at least, report having already incorporated this goal into their daily praxis. Researchers have identified that localized political threats can inspire cooperation across movements [39], and this was certainly the case following Bush's war in Iraq [49]. Could the same hold true for Trump's presidency? While Trump-era conservativism may be ideologically corrosive to social movements in encouraging them to retain a single-issue focus, the national resistance to the Republican agenda is also creating a point of convergence for social justice movements. Future research following the completion of Trump's tenure could provide a useful point of comparison, as would research investigating the mobilizing effect of his presidency.

Supplementary Materials: The following are available online at www.mdpi.com/2075-4698/7/4/32/s1.

Conflicts of Interest: The author declares no conflict of interest.

\section{References}

1. Newport, F. In U.S., 5\% Consider Themselves Vegetarians. Available online: http://www.gallup.com/poll/ 156215/Consider-Themselves-Vegetarians.aspx (accessed on 1 July 2017).

2. How Many Adults in the U.S. Are Vegetarian and Vegan? Available online: http://www.vrg.org/nutshell/ Polls/2016_adults_veg.htm (accessed on 1 July 2017).

3. Maurer, D. Vegetarianism: Movement or Moment? Temple University Press: Philadelphia, PA, USA, 2002; ISBN 978-1-56639-936-4.

4. Monteiro, C.; Pfeiler, T.; Patterson, M.; Milburn, M. The carnism inventory: Measuring the ideology of eating animals. Appetite 2017, 113, 51-62. [CrossRef] [PubMed]

5. Ruby, M. Vegetarianism. A blossoming field of study. Appetite 2011, 58, 141-150. [CrossRef] [PubMed]

6. Funk, C.; Kennedy, B. The New Food Fights: U.S. Public Divides over Food Science. Available online: http:/ / www.pewinternet.org/2016/12/01/the-new-food-fights/ (accessed on 29 August 2017).

7. Jamison, W.; Lunch, W. Rights of animals, perceptions of science, and political activism: Profile of American animal rights activists. Sci. Technol. Hum. Values 1992, 17, 438-458. [CrossRef]

8. McGarry, A.; Jasper, J. (Eds.) Introduction: The identity dilemma, social movements, and contested identity. In Identity Dilemma; Temple University Press: Philadelphia, PA, USA, 2015; pp. 1-17, ISBN 1439912521.

9. Chasin, A. Selling Out: The Gay and Lesbian Movement Goes to Market; Palgrave: New York, NY, USA, 2000; ISBN 0312239262.

10. Ryan, B. Feminism and the Women's Movement: Dynamics of Change in Social Movement Ideology and Activism; Routledge: New York, NY, USA, 1992; ISBN 0415905990.

11. Beers, D. For the Prevention of Cruelty; Ohio University Press: Athens, GA, USA, 2006; ISBN 0804010870.

12. Harper, B. Race as a 'feeble matter' in veganism: Interrogating whiteness, geopolitical privilege, and consumption philosophy of 'cruelty-free' politics. J. Crit. Anim. Stud. 2010, 8, 5-27.

13. Kymlicka, W.; Donaldson, S. Animal rights, multiculturalism and the left. J. Soc. Philos. 2013, 45, 116-135. [CrossRef]

14. Hughey, M. Show me your papers! Obama's birth and the whiteness of belonging. Qual. Sociol. 2012, 34, 163-181. [CrossRef]

15. Harper, B. Make Veganism Great Again. Wesleyan University, 3 March 2017, Lecture. Available online: http:/ / www.sistahvegan.com/2017/03/12/make-veganism-great-again-keeping-the-negro-out-of-thepost-racial-vegan-foodscape/ (accessed on 11 November 2017).

16. Collectively Free. Available online: http:/ /www.collectivelyfree.org/your-organizer-voted-for-trump-nowwhat/ (accessed on 1 July 2017).

17. Davis, J. The Gospel of Kindness: Animal Welfare \& the Making of Modern America; Oxford University Press: New York, NY, USA, 2016; ISBN 0199733155.

18. Lundblad, M. The Birth of a Jungle: Animality in Progressive-Era U.S. Literature and Culture; Oxford University Press: New York, NY, USA, 2013; ISBN 0190231580.

19. Deckha, M. Welfarist and imperial: The contributions of anticruelty laws to civilization discourse. Am. $Q$. 2013, 65, 515-548. [CrossRef] 
20. Ferguson, M. Animal Advocacy and Englishwomen, 1780-1900: Patriots, Nation, and Empire; The University of Michigan Press: Ann Arbor, MI, USA, 2001, ISBN 0472108743.

21. Birkeland, J. Ecofeminism: Linking theory and practice. In Ecofeminism; Gaard, G., Ed.; Temple University Press: Philadelphia, PA, USA, 1993; pp. 13-59, ISBN 0877229899.

22. Ohrem, D. A declaration of interdependence: American history and the challenges of postanthopocentric historiography. In American Beasts: Perspectives on Animals, Animality and U.S. Culture, 1776-1920; Ohrem, D., Ed.; Neofelis Verlag: Berlin, Germany, 2017; pp. 9-48, ISBN 3958080375.

23. Socha, K. The 'dreaded comparisons' and speciesism: Leveling the hierarchy of suffering. In Confronting Animal Exploitation; Socha, K., Blum, S., Eds.; McFarland \& Company, Inc.: Jefferson, MO, USA, 2013; pp. 223-240, ISBN 0786465751.

24. Adams, C.; Gruen, L. Ecofeminism; Bloomsbury: New York, NY, USA, 2014; ISBN 1628928034.

25. Regan, T. The Torch of Reason: The War on Vivisection. Available online: http://tomregan.info/the-torchof-reason/ (accessed on 1 July 2017).

26. Rothwell, J.; Diego-Rosell, P. Explaining Nationalist Political Views: The case of Donald Trump. SSRN, 2 November 2016. Available online: https://papers.ssrn.com/sol3/papers.cfm?abstract_id=2822059 (accessed on 29 August 2017).

27. Reicher, S.; Haslam, S. The politics of hope: Donald Trump as an entrepreneur of identity. In Why Irrational Politics Appeals; Fitzduff, M., Ed.; Praeger: Santa Barbara, CA, USA, 2017; pp. 25-40, ISBN 1440855145.

28. Harper, B. Whiteness: Breeze Harper. The Secret Ingredient, 2016, 18. National Public Radio. Available online: http:/ /www.sistahvegan.com/2016/09/07/ podcast-secret-ingredient-of-whiteness-raceethical-foodscapes-and-intersectional-anti-racism/ (accessed on 14 November 2017).

29. Francione, G. Animal Rights: The Abolitionist Approach. Available online: http:/ / www.abolitionistapproach. com/selfie-morality-the-moral-rot-of-the-animal-movement (accessed on 1 July 2017).

30. Phelps, N. The Longest Struggle: Animal Advocacy from Pythagoras to PETA; Lantern: New York, NY, USA, 2007; ISBN 1590561066.

31. Stallwood, K. GROWL: Life Lessons, Hard Truths, and Bold Strategies from an Animal Advocate; Lantern: Brooklyn, NY, USA, 2014; ISBN 9781590563960.

32. Wrenn, C. Professionalization, Factionalism, and Social Movement Success: A Case Study on Nonhuman Animal Rights Mobilization. Ph.D. Thesis, Colorado State University, Fort Collins, CO, USA, 2016.

33. Francis, R. Fruitlands: The Alcott Family and Their Search for Utopia; Yale University Press: New Haven, CT, USA, 2010; ISBN 0300177909.

34. Weinbren, D. Against all cruelty: The humanitarian league, 1891-1919. Hist. Workshop 1994, 38, 86-105. [CrossRef]

35. Kean, H. The 'smooth cool men of science': The feminist and socialist response to vivisection. Hist. Workshop J. 1995, 40, 16-38. [CrossRef]

36. Rodríquez, D. The political logic of the non-profit industrial complex. In The Revolution Will Not Be Funded: Beyond the Non-Profit Industrial Complex; INCITE!, Ed.; South End Press: Cambridge, MA, USA, 2007; pp. 21-40.

37. Obach, B. Political opportunity and social movement coalitions: The role of policy segmentation and nonprofit tax law. In Strategic Alliances: Coalition Buildings and Social Movements; Van Dyke, N., McCammon, H., Eds.; University of Minnesota Press: Minneapolis, MN, USA, 2010; pp. 197-218, ISBN 0816667349.

38. Hess, A. How a Fractious Women's Movement Came to Lead the Left. Available online: https://www. nytimes.com/2017/02/07/magazine/how-a-fractious-womens-movement-came-to-lead-the-left.html (accessed on 1 July 2017).

39. Van Dyke, N. Crossing movement boundaries: Factors that facilitate coalition protest by American college students, 1930-1990. Soc. Probl. 2003, 50, 226-250. [CrossRef]

40. Beamish, T.; Luebbers, A. Alliance building across social movements. Soc. Probl. 2014, 56, 647-676. [CrossRef]

41. Cruz, S. The relationships of political ideology and party affiliation with environmental concern. J. Environ. Psychol. 2017, 53, 81-91. [CrossRef]

42. Gamson, J. The dilemma of identity politics. In The Social Movements Reader; Goodwin, J., Jasper, J., Eds.; Wiley-Blackwell Publishing: Hoboken, NJ, USA, 2003; pp. 335-343.

43. Gusterson, H. From Brexit to Trump: Anthropology and the rise of nationalist populism. Am. Ethnol. 2017, 44, 209-214. [CrossRef] 
44. Hodson, G.; Earle, M. Conservativism predicts lapses from vegetarian/vegan diets to meat consumption. Appetite 2018, 120, 75-81. [CrossRef]

45. Menzies, K.; Sheeshka, J. The processes of exiting vegetarianism: An exploratory study. Can. J. Diet. Pract. Res. 2012, 73, 163-168. [CrossRef] [PubMed]

46. Twine, R. Negotiating social relationships in the transition to vegan eating practices. In Meat Culture; Potts, A., Ed.; Brill: Leiden, The Netherlands, 2017; pp. 243-263, ISBN 9789004325845.

47. Corrigall-Brown, C.; Meyer, D. The prehistory of a coalition: The role of social ties in win without war. In Strategic Alliances: Coalition Buildings and Social Movements; Van Dyke, N., McCammon, H., Eds.; University of Minnesota Press: Minneapolis, MN, USA, 2010; pp. 3-21, ISBN 0816667349.

48. Cornfield, D.; McCammon, H. Approaching merger: The converging public policy agendas of the AFL and CIO, 1938-1955. In Strategic Alliances: Coalition Buildings and Social Movements; Van Dyke, N., McCammon, H., Eds.; University of Minnesota Press: Minneapolis, MN, USA, 2010; pp. 79-98, ISBN 0816667349.

49. Reese, E.; Petit, C.; Meyer, D. Sudden mobilization: Movement crossovers, threats, and the surprising rise of the U.S. antiwar movement. In Strategic Alliances: Coalition Buildings and Social Movements; Van Dyke, N., McCammon, H., Eds.; University of Minnesota Press: Minneapolis, MN, USA, 2010; pp. 226-291, ISBN 0816667349.

(c) 2017 by the author. Licensee MDPI, Basel, Switzerland. This article is an open access article distributed under the terms and conditions of the Creative Commons Attribution (CC BY) license (http:/ / creativecommons.org/licenses/by/4.0/). 